УДК 619.614.48:579.873.21

(C) 2012

Палій А. П., кандидат ветеринарних наук,

Завгородній А. І., доктор ветеринарних наук, член-кореспондент НААН

Національний науковий центр «Інститут експериментальної і клінічної ветеринарної медицини»

\title{
ВПЛИВ БАКТЕРИЦИДНИХ КОНЦЕНТРАЦЙ ДЕЗЗАСОБІВ «ДЗПТ-2» ТА «ЕКОЦИД С» НА УЛЬТРАСТРУКТУРУ МІКОБАКТЕРІЙ
}

\section{Рецензент - доктор ветеринарних наук Н. П. Чечоткіна}

Електронно-мікроскопічними дослідженнями встановлені суттєві ультраструктурні зміни в клітинах атипових мікобактерій M. kansasii, M. gordonae, M. xепорi, M. flavescens після виливу альдегідного дезінфектанту «ДЗПТ-2» та кисневого препарату «Екоичид С». Відмічена різниия у діi деззасобів на мікробні клітини, щуо пов'язано з особливостями механізму дї активнодіючих речовин, які входять до їхнього складу. Встановлено,

щзо дезінфікуючі препарати в бактерицидних

режимах знищують мікобактерії за рахунок створення незворотних змін їх субмікроскопічної організації.

Ключові слова: електронна мікроскопія, мікобактерії, ультраструктура, дезінфектант, «ДЗПТ-2», «Екоичид С».

Постановка проблеми. Досконале й всебічне вивчення збудників інфекційних захворювань на молекулярному рівні має важливе значення в розумінні окремих питань патогенезу, в розробці методів і засобів діагностики та лікування хвороби. Не дивлячись на вельми тривалу історію застосування багатьох дезінфікуючих засобів, на даний час немає достатньо повного уявлення, яке б відображало динаміку та різноманіття пошкоджень у клітинах, що виникають при контакті $з$ тим чи іншим препаратом.

Аналіз основних досліджень і публікацій, у яких започатковано розв'язання проблеми. В останні роки, в зв'язку з формуванням у бактерій (у тому числі й мікобактерій) стійкості до дезінфікуючих засобів, розробляються комплексні препарати, складові компоненти яких володіють високою антимікробною активністю і широким спектром бактерицидних властивостей [1]. Проте обмежена інформація щодо механізмів летальної дії на мікроорганізми ряду хімічних сполук із бактерицидними властивостями, які вже використовуються або є перспективними для проведення профілактичної та вимушеної дезінфекції при інфекційних хворобах, збудники яких є високостійкими до негативних чинників.

Встановлено, що найбільш загальними харак- терними змінами в ультраструктурі кишкової палички та стафілокока (при дії аніонного та мийно-дезінфікуючого засобу «Збруч») є руйнація цитоплазматичної мембрани бактерій, а функціональні зміни мікроорганізмів полягають у різкому пригніченні діяльності дегідрогеназ i глюкозидаз мікроорганізмів [2]. Висока бактерицидна та спороцидна дії надоцтової кислоти пояснюється іiї високою проникністю через мікробну клітину [3].

Отримані дані електронної мікроскопії підтвердили бактерицидну активність деяких альдегідних дезінфектантів щодо збудників туберкульозу та атипових мікобактерій; встановлені деструктивні зміни мікробів [4].

Узагальнюючи факти, що характеризують дію фенолу на бактерії, можна дійти висновку, що препарат взаємодіє з білковими компонентами клітини, порушує проникність цитоплазматичної мембрани, а вихід низькомолекулярних продуктів із цитоплазми супроводжується пригніченням енергетичних процесів [5].

Детальне вивчення субмікроскопічних процесів, що перебігають у бактеріальній клітині при дії дезінфікуючих засобів, допоможе розкрити складний механізм їхньої дії та $\epsilon$ справжньою науковою основою в синтезі нових бактерицидних засобів.

Мета роботи. Вивчити вплив альдегідного та кисневого дезінфікуючих препаратів на ультраструктурну організацію окремих атипових мікобактерій.

Матеріали і методи досліджень. Ультраструктурні зміни після дії дезінфікуючих препаратів вивчали в атипових мікобактерій, що відносяться до різних груп за класифікацією Раньона: I група - Mycobacterium kansasii; II група - Mycobacterium gordonae; III група - Mycobacterium xenopi; IV група - Mycobacterium flavescens.

Тест-культури мікобактерій мали типові культуральні та біологічні властивості, характерні для даних видів.

У якості дезінфікуючих препаратів у дослідах 
застосовували засіб із групи альдегідів - «ДЗПТ$2 »$ (2\% за ДР - 24 год.) та кисневий препарат «Екоцид С» $(5 \%$ - 24 год.) у туберкулоцидних режимах [6]. Проведення досліджень 3 оцінки бактерицидної дії дезінфікуючих препаратів щодо тест-культур мікобактерій здійснювали відповідно до методичних рекомендацій «Визначення бактерицидних властивостей дезінфікуючих засобів, проведення дезінфекції та контроль iï якості при туберкульозі сільськогосподарських тварин» (Затв. Держ. комітетом вет. мед. України 20.12.2007 р.) за допомогою суспензійного способу.

Проведення електронно-мікроскопічного дослідження проводили згідно із загальноприйнятою методикою (Б. Уикли, 1975), а ультраструктуру мікобактеріальних клітин досліджували за допомогою електронного мікроскопа ПЭМ-125К.

Результати досліджень. Ультраструктурні зміни після дії бактерицидних концентрацій препаратів «ДЗПТ-2» та «Екоцид С» у культури $M y$ cobacterium kansasii представлені на рис. 1 і 2.

Після дії на M. kansasii дезінфектанту «ДЗПТ2» відмічали розчинення мікрокапсули та клітинної стінки. Частково у клітин була відсутня цитоплазматична мембрана. Цитоплазма мала вигляд темних дрібногранулярних включень. Область нуклеоїду не проглядається.

Препарат «Екоцид С» зумовлює тенденцію клітин до злипання внаслідок зміни поверхнево-

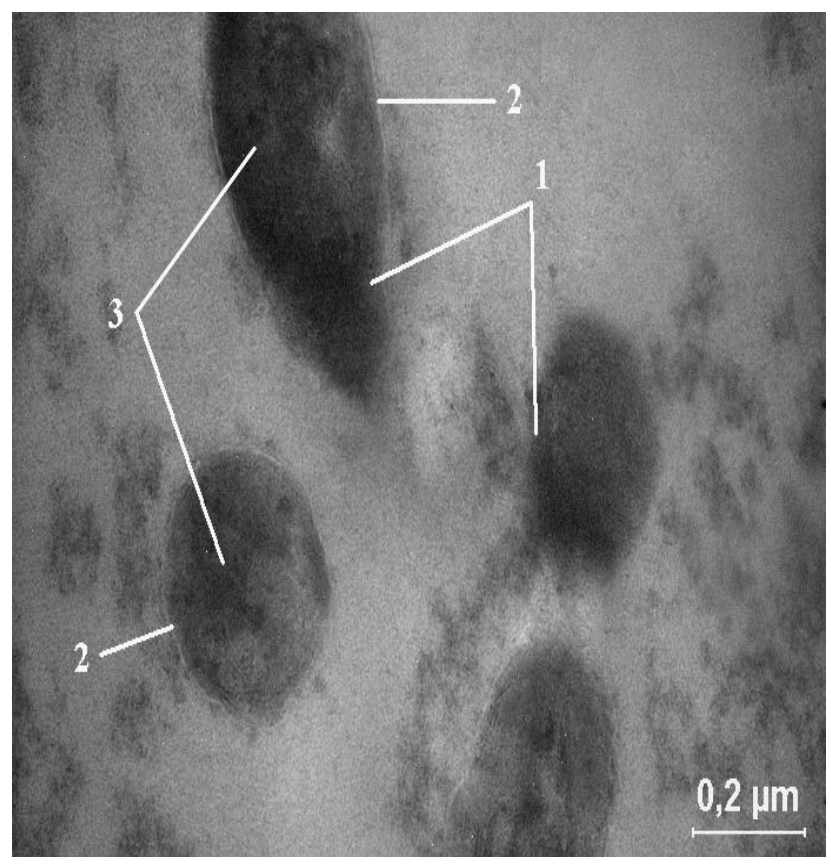

Pис. 1. M. kansasii niсля дї̈ «ДЗПТ-2»

1 - відсутність поверхневих структур; 2 - иитоплазматична мембрана; 3 - иитоплазма го електричного заряду. Відмічали руйнацію клітинної стінки з виходом цитоплазми на зовні.

При дії дезінфікуючих препаратів на культуру Mycobacterium gordonae виникають зміни, представлені на рис. 3 і 4.

Після застосування «ДЗПТ-2» у M. gordonae спостерігали появу в цитоплазмі клітин вакуолей, які мали низьку електронну щільність. Клітинна стінка та цитоплазматична мембрана частково розмиті. Цитоплазма представлена дрібними осміофільними гранулами.

Препарат «Екоцид С» у M. gordonae зумовлює повне розчинення поверхневих структур мікобактерій, при цьому цитоплазма контактує з навколишнім середовищем. Цитоплазма представлена розмитою гомогенною масою, вміщує вакуолі. В області нуклеоїду проглядаються скупчення осміофільного конгломерату.

Зміни, що виникають у мікобактерій Mycobacterium xепорі, після дії деззасобів представлені на рис. 5 і 6 . При дії на $M$. хепорi деззасобу «ДЗПТ-2» відмічали відсутність мікрокапсули та клітинної стінки практично в усіх мікробних клітин. Цитоплазма містила дрібногранулярні субстанції різної електронної щільності.

У M. xепорi препарат «Екоцид С» обумовлює тотальну руйнацію поверхневих структур бактеріальних клітин, у цитоплазмі відсутні включення, область нуклеоїду не проглядається.

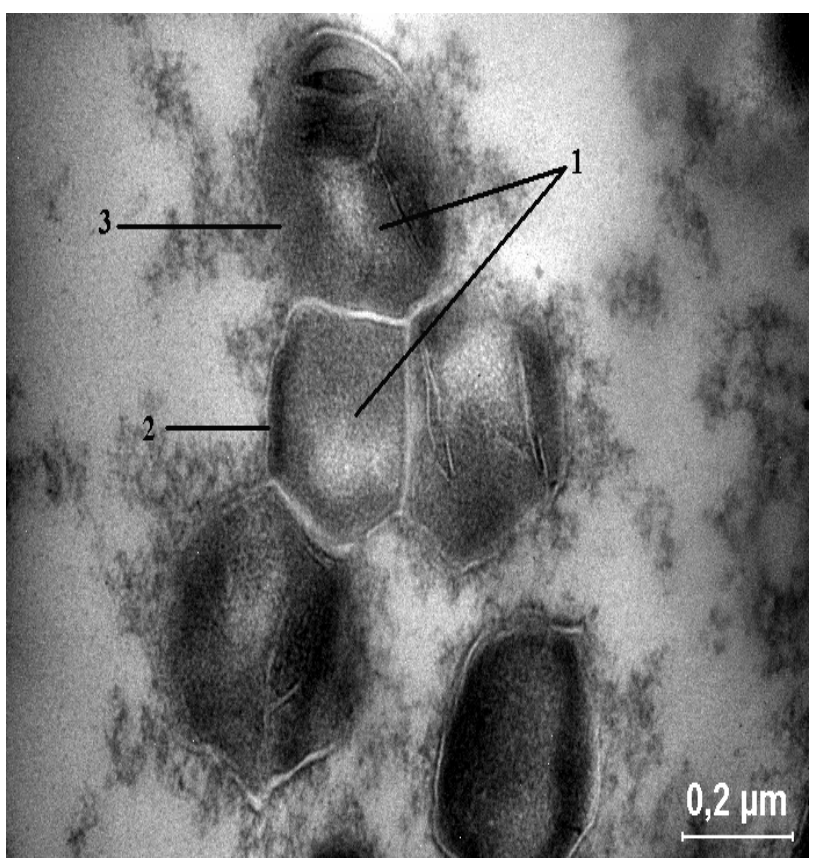

Pис. 2. M. kansasii після дії «Екоцид С» 1 - ичтооллазма; 2 - ичтооллазматична мембрана; 3 -лізис клітинної стінки та вихід циитоплазми назовні 


\section{ВЕТЕРИНАРНА МЕДИЦИНА}

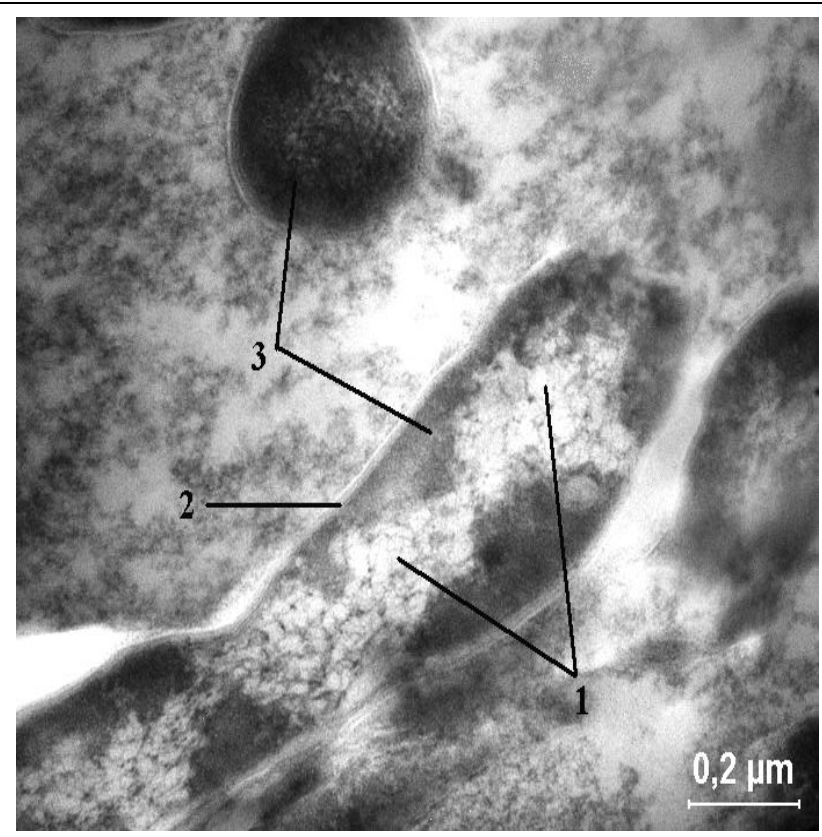

Pис. 3. M. gordonae після дії "ДЗПТ-2»

1 - вакуолі; 2 - клітинна стінка;

3 - цитоплазма

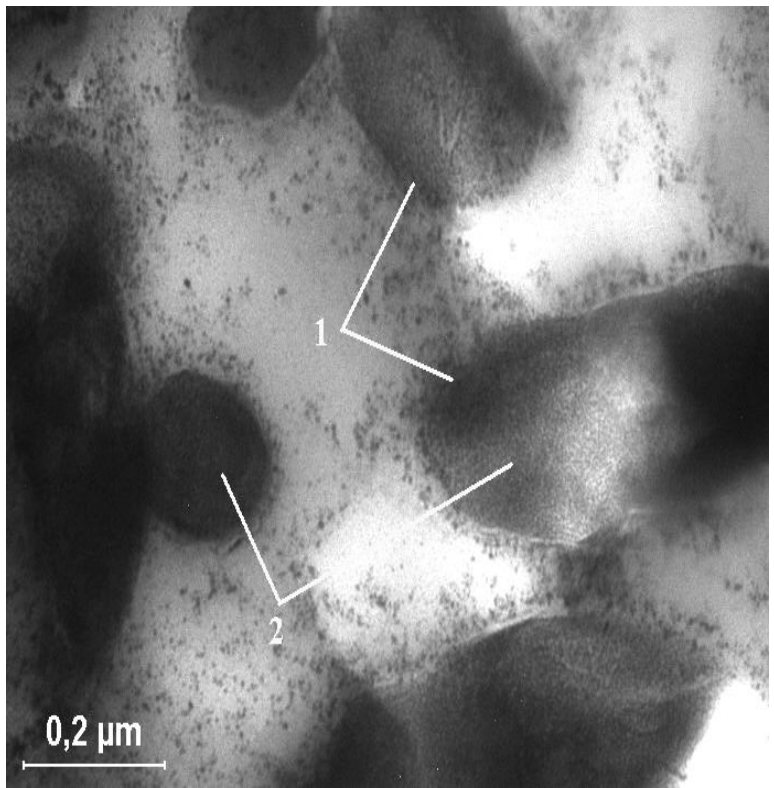

Рис. 5. М. хепорі після дії «ДЗПТ-2»

1 - відсутність поверхневих структур; 2 - иитоплазма.

Після дії «ДЗПТ-2» у культури M. flavescens спостерігали повну руйнацію мікрокапсули та клітинної стінки. У цитоплазмі виявляються осміофільні включення високої електронної щільності.

За дії деззасобу «Екоцид С» на M. flavescens спостерігали часткове порушення мікрокапсули. Клітинна стінка зруйнована, відходить від про-

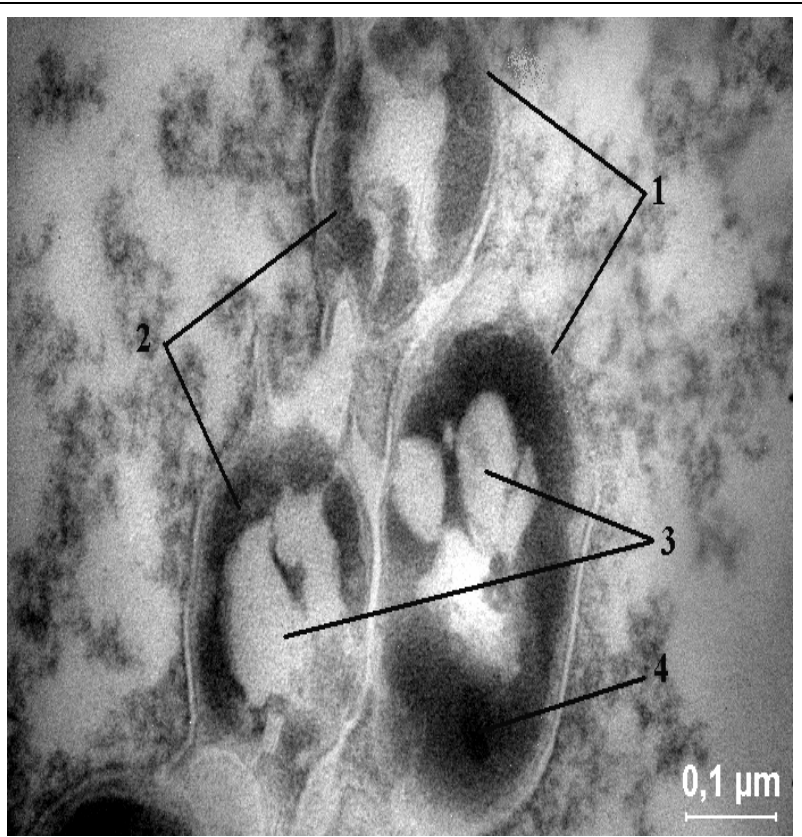

Pис. 4. M. gordonaе після дії «Екоцид С» 1 - розчинення поверхневих структур; 2 - изитоплазма; 3 - вакуолі; 4 -область нуклеоїу

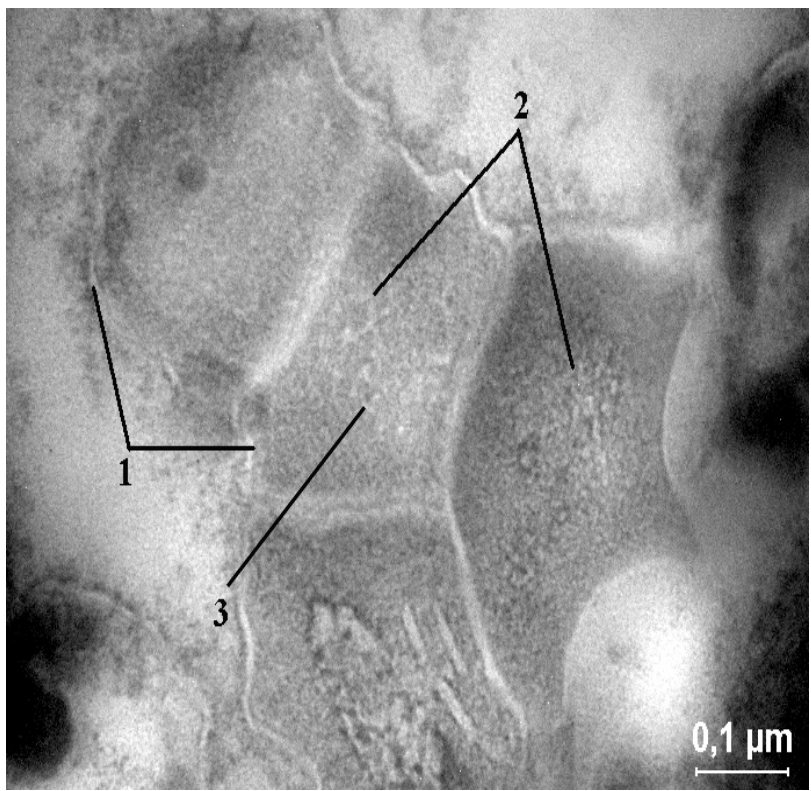

Рис. 6. М. хепорі після дії «Екоцид С» 1 - клітинна стінка; 2 - цитоплазма; 3 - область нуклеоїду.

топласту (рис. 7,8 ).

У цитоплазмі спостерігаються локальні порушення структури та відсутність гранулярного компоненту.

Нуклеоїд в окремих клітинах зберігає структуру, в більшості клітин спостерігається концентрація білкового ДНК-вмісного матеріалу в центральній частині нуклеоїду. 


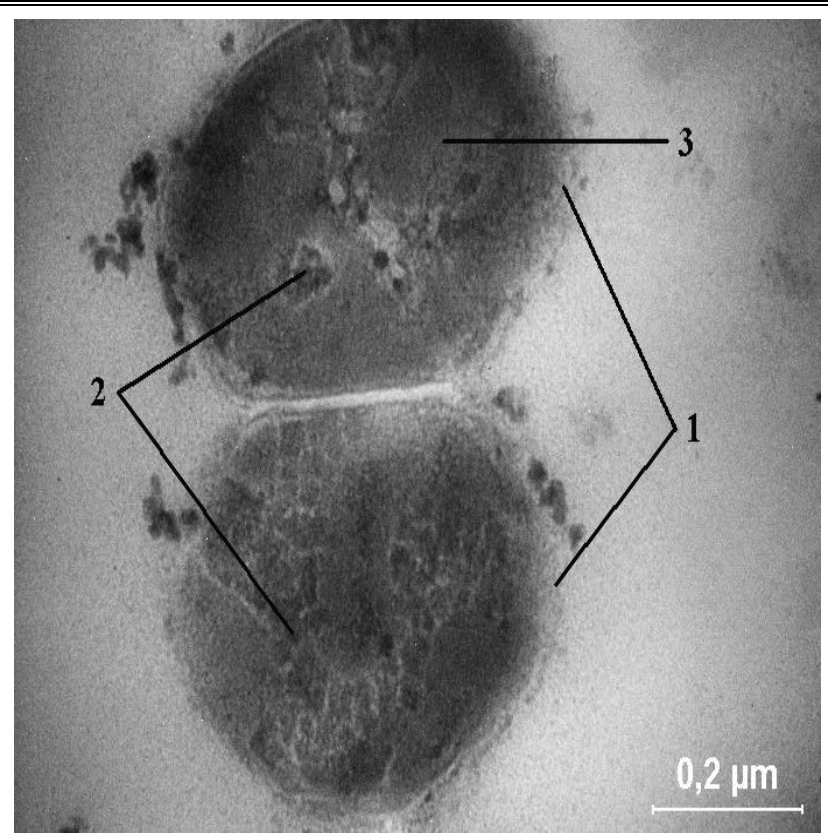

Рис. 7. М. flavescens після дї̈ «ДЗПТ-2» 1 - руйнація поверхневих структур; 2 -осміофільні включення; 3 - цитоплазма

\section{Висновки:}

1. Зміни, що виникають у мікобактерій після дії альдегідного деззасобу, характеризуються руйнацією мікрокапсули, клітинної стінки, цитоплазматичної мембрани, утворенням у цитоплазмі клітин вакуолей та осміофільних включень. Альдегідний препарат передусім вступає у взаємодію з білковими компонентами мембранних структур і ферментами клітини завдяки високій реакційній здатності щодо амінокислот, білків, нуклеїнових кислот. Інактивація мікобактерій виникає внаслідок зниження синтезу макромолекул у бактеріальних клітинах.

\section{БІБЛІОГРАФІЯ}

1. Коваленко В. Л. Теоретичне і експериментальне обгрунтування розробки та використання комплексних дезінфектантів для ветеринарної медицини [Текст]. / Автореф. дис. ... док. вет. наук : 16.00.06. - К., 2012. - 43 с.

2. Куликовский $A$. В. структурные и функциональные основы механизма действия дезинфицирующих средств на бактерии и споры [Текст] / Автореф. дис. ... док. вет. наук : 03.00.07. - М., 1979. $-50 \mathrm{c}$.

3. Павлова И. Б. Субмикроскопическое изучение бактерий и спор при воздействии надуксусной кислоты и некоторые аспекты механизма действия препарата [Текст] / И. Б. Павлова, А. В. Ку-

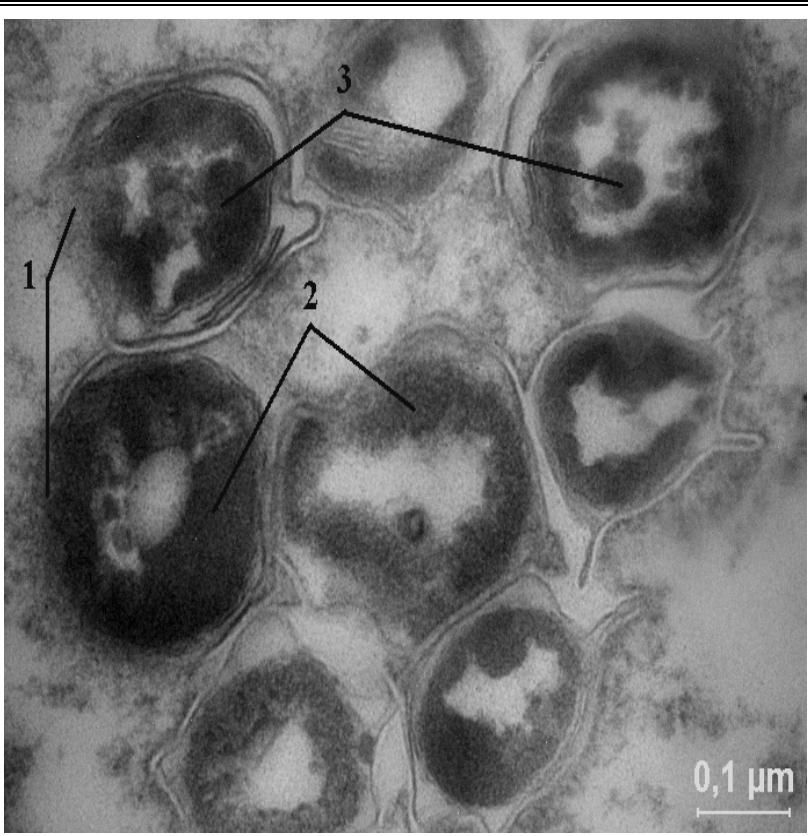

Pис. 8. M. flavescens nісля дї «Екоцид С» 1 - порушення мікрокапсули та клітинної стінки; 2 - цитоплазма; 3 - нуклеої

2. Кислотний препарат зумовлює тотальну руйнацію клітинної стінки та цитоплазматичної мембрани, деструкцію гранулярного компоненту цитоплазми 3 утворенням у ній осміофільних дрібногранулярних включень та електроннопрозорих вакуолей. Основною причиною, що призводить до загибелі мікобактерій, є руйнація клітинної стінки бактерій. Це пов'язано з омиленням ліпідів як самої стінки, так і цитоплазми. Кислотний препарат окислює білки та ліпіди мембранних структур, порушує проникність клітин, інгибує окислювально-відновлювальні реакції.

ликовский // ЖМЭИ. - 1978. - № 1. - С. 37-40. 4. Пономаренко Г. В. Оцінка ефективності бактерицидної дії дезінфікуючих препаратів на мікобактерії [Текст] / Автореф. дис. ... канд. вет. наук : 16.00.03. - Х., 2004. - 20 c.

5. Костина Г. И. К вопросу о механизмах химической инактивации микроорганизмов [Текст] / Г. И. Костина // ЖМЭИ. - 1981. - № 8. - С. 25-32.

6. Завгородній A. I. Удосконалення методичних підходів щодо визначення бактерицидних властивостей нових деззасобів [Текст] / А. І. Завгородній, А. П. Палій, Г. В. Пономаренко, С. А. Ничик // Вет. медицина: Міжвід. тематич. наук. зб. - Х., 2011 - Вип. 95. - С. 29-31. 